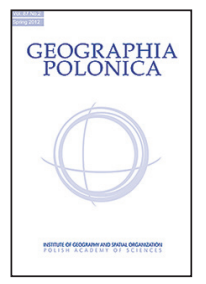 \\ INSTITUTE OF GEOGRAPHY AND SPATIAL ORGANIZATION \\ POLISH ACADEMY OF SCIENCES \\ www.igipz.pan.pl \\ www.geographiapolonica.pl
}

\title{
MAIN PROBLEMS OF TRANSPORT INFRASTRUCTURE DEVELOPMENT IN SLOVAKIA AND EFFECTS ON REGIONAL DEVELOPMENT
}

\section{Daniel Michniak}

Institute of Geography

Slovak Academy of Sciences

Štefánikova 49, 81473 Bratislava: Slovakia

e-mail: geogmich@savba.sk

\begin{abstract}
The aim of this article is to examine the development of transport infrastructure (modernisation of railway tracks and development of the motorway and expressway network) and its possible effects on regional development in Slovakia. Accessible transport infrastructure (mainly the motorway network) has influenced many decisions concerning the location of industrial investments. The impact of transport infrastructure on the reduction of regional disparities in Slovakia is limited mainly due to the concentration of transport infrastructure investment in the more developed regions of Slovakia. Poorer regions in eastern Slovakia and the southern part of Central Slovakia are still affected by the unfavourable level of accessibility to the transport infrastructure that creates important conditions affecting their development.
\end{abstract}

\section{Key words}

transport infrastructure development - regional development - travel time - industrial investment location • regional disparities $\bullet$ regional structure $\bullet$ Slovakia

\section{Introduction}

Transport and transport infrastructure have played an important role in the development of regions and centres. During recent centuries different transport modes have been crucial accelerators of regional development. Of the individual elements of transport infrastructure, while railways were fundamental for regional economic development in the 19th and early 20th centuries, roads (mainly motorways or expressways) played a dominant role in the 20th century and in the later part of 20th century airports, airways and information channels assumed this role.

The development of transport infrastructure has reached different levels in different parts of Europe. The network of motorways and expressways in Western European countries is almost complete and nowadays they are only 
adjusted or complemented by smaller sections. Such countries can invest in railways and air transport, e.g. the construction of high-speed railways and building of new airport terminals. These investments in transport infrastructure can contribute to the increase in competitiveness of regions that are better connected with other centres and regions. By contrast in the majority in the post-socialist countries of Central and Eastern Europe the process of construction of motorways is only halfway complete. In these countries infrastructure, predominantly road (motorways and expressways), is still very important for regional development.

The aim of this article is to outline some remarks on the development of transport infrastructure in Slovakia and its possible effects on regional development. There are many questions that should be answered in this context: What is the role of transport and transport infrastructure in regional development? Which sectors are most affected by transport infrastructure? In which regions of Slovakia has a quality transport infrastructure been built? Can the construction of motorways and expressways or modernisation of railways contribute to the reduction of regional disparities in Slovakia?.

The structure of the article corresponds to these questions. The first part of the article concerns the development of railways (modernisation of railway tracks) and development of the motorway and expressway network. In the second part attention is paid to the impact of transport infrastructure on travel time, on the location of industrial investment and other selected impacts of transport infrastructure. The last part of the article discusses the impact of transport infrastructure on regional structure and regional disparities in Slovakia.

\section{The role of transport and transport infrastructure in regional development}

There is wide-ranging discussion on the topic of the impact of transport and transport infrastructure on economic and regional development in the scientific literature. But it is difficult to identify the precise nature of the relationship between transport infrastructure and regional development (Vickerman 1996). Recent international research has reinforced the links between transport investment and the improved economic performance of firms and regions (e.g. Banister \& Thurstain-Goodwin 2011; Lakshmanan 2011; Banerjee et al. 2012; Crescenzi \& Rodríguez-Pose 2012; Gibbons et al. 2012; Hensher et al. 2012; Albarran et al. 2013; Rodrigue et al. 2013; Knowles \& Ferbrache 2014; Redding \& Turner 2014).

Transport and transport infrastructure can impact regional development in a direct, indirect or related way. Rodrigue et al. (2013) states that the direct impacts of transport on economic development (also known as induced impacts) are the outcome of accessibility changes where transport enables employment and added value to increase, and provides larger markets and time and cost savings. Indirect impacts are the outcome of economic multiplier effects where the price of commodities, goods or services drops and/or the range on offer increases and the related impacts are the outcome of economic activities and firms partly relying on efficient transport services for both passengers and freight. According to Marada et al. (2006) direct impacts include an increase in employment in the construction sector during the process of construction of infrastructure, a reduction of fuel consumed, a saving in time or a reduction in environmental problems (concerning pollution and noise) and indirect impacts are those on the productivity of the regional economy, location of companies, behaviour of households or effects on the price of property.

The improvement of transportation infrastructure leads to a reduction in travel time or cost and hence improvement in accessibility. The lower costs and increased accessibility due to transport improvements modify the marginal costs of producers, and increase both the mobility of households and the demand for goods and services (Lakshmanan 2011). New or improved infrastructure may have both positive and negative economic effects for any region that are influenced by the consequent 
reduction in the costs of communication. For some sectors and products increased accessibility may boost that region's exports, whereas for other sectors and products it may lead to increased competition on its home market and a contraction of local output, income and employment (Oosterhaven \& Knaap 2003). The effect of new transport infrastructure is not necessarily positive for all of regions. Some of them may be negatively influenced, e.g. by the loss of markets due to increasing competition (Rietveld \& Nijkamp 1992).

Banister and Thurstain-Goodwin (2011) distinguish three levels of economic effects of infrastructure investment: macro-economic effects - impacts on economic growth; mesoeconomic effects - impacts on agglomeration economies and labour market; and micro-economic effects - impacts on land and property values and these indicate a need to carry out analysis on all levels using appropriate methods.

The resulting effect of transport infrastructure investments on regional development depends on their size and scale. Effects of transport infrastructure can be short-term or long-term, respectively temporary or permanent. Similar investment in transport infrastructure in different regions may have different impacts. Effects of infrastructure investments depend also on the level of regional development. Benefits of infrastructure are lower in regions, which are already developed compared to developing or lagging regions (Lall 2007). Impacts of transport can precede, occur during, or take place after economic development (Rodrigue et al. 2013).

Infrastructure is only one of the instruments for improving the development of a certain region, but it is very important because it is the base of many other socio-economic activities in a country or region (Nijkamp 1986). Transport by itself is not a sufficient prerequisite for development. However, the lack of transport infrastructures can be seen as a constraining factor for development. A poor level of transport service can negatively affect the competitiveness of regions and corporations and thus have a negative impact on regional added value and employment (Rodrigue et al. 2013). Regions and locations with poor quality transport are at a competitive disadvantage. Transport infrastructure is only one of the factors, which influence regional development. For the successful economic development of a region, good economic and political conditions are also necessary (Banister \& Berechman 2001).

Transport infrastructure has been the cornerstone of EU regional development policy for a long time. The EU has placed huge emphasis on transport infrastructure investment, with the aim of promoting territorial cohesion, reducing economic disparities, and promoting economic development (Crescenzi \& Rodríguez-Pose 2012).

\section{Development of the railway network}

The existing railway network in Slovakia is the result of about 150 years of development that took place in different political and economic conditions with different economic and strategic objectives and priorities. The impact of the railways was especially important for the development of regions when it became the decisive locational incentive for industry in the 19th century and at the beginning of the 20th century. Its significance is obvious as exemplified by a couple of towns where the construction of the railway meant the development of one of them and its absence caused stagnation of the other. The building of the Košice - Bohumín railway track supported the development of Poprad at the cost of Kežmarok, the development of Spišská Nová Ves and stagnation of Levoča. Likewise, the railway track from Bratislava to Trnava spurred the progress of Pezinok and slowed down that of Modra.

The most important railway route in Slovakia is the track Bratislava - Žilina - Košice (consisting of the 1st category tracks Nos. 120 and 180), which along with the southern connection Bratislava - Zvolen - Košice forms the basic skeleton of country's railway network. The railway network in Slovakia has been practically unchanged for a long time 
following its gradual construction. The railway network in Slovakia and the Pan-European transport corridors in the railway network are shown in Figure 1.

There have been efforts to improve railway transport via the modernisation of railway infrastructure in Slovakia (Tab. 1). This modernisation concentrates mainly in the western part of the country on the main track in Slovakia from Bratislava - Žilina. By 2014 a continuous 114 km long track Bratislava-Rača - Zlatovce had been adapted for a speed of $160 \mathrm{~km} / \mathrm{h}$. In addition a section of the main railway track, the $19 \mathrm{~km}$ section between Žilina and Krásno nad Kysucou, had also been upgraded.
As of 30 June 2013 a total of one billioneuros has been invested into construction works for railways. More than a half of these funds (572 million) were from the EU from the preaccession ISPA and Cohesion Funds. Investments in the modernisation of the railway infrastructure (increasing the speed limit up to $160 \mathrm{~km} / \mathrm{h}$ ) concentrate in the western part of Slovakia.

The construction of new high-speed railway lines, like those that have been built in several EU countries, is not being contemplated in Slovakia. There are some visions, but at present there is a lack of finance and other priorities. However, in the future, the construction of a high-speed railway track as part of the

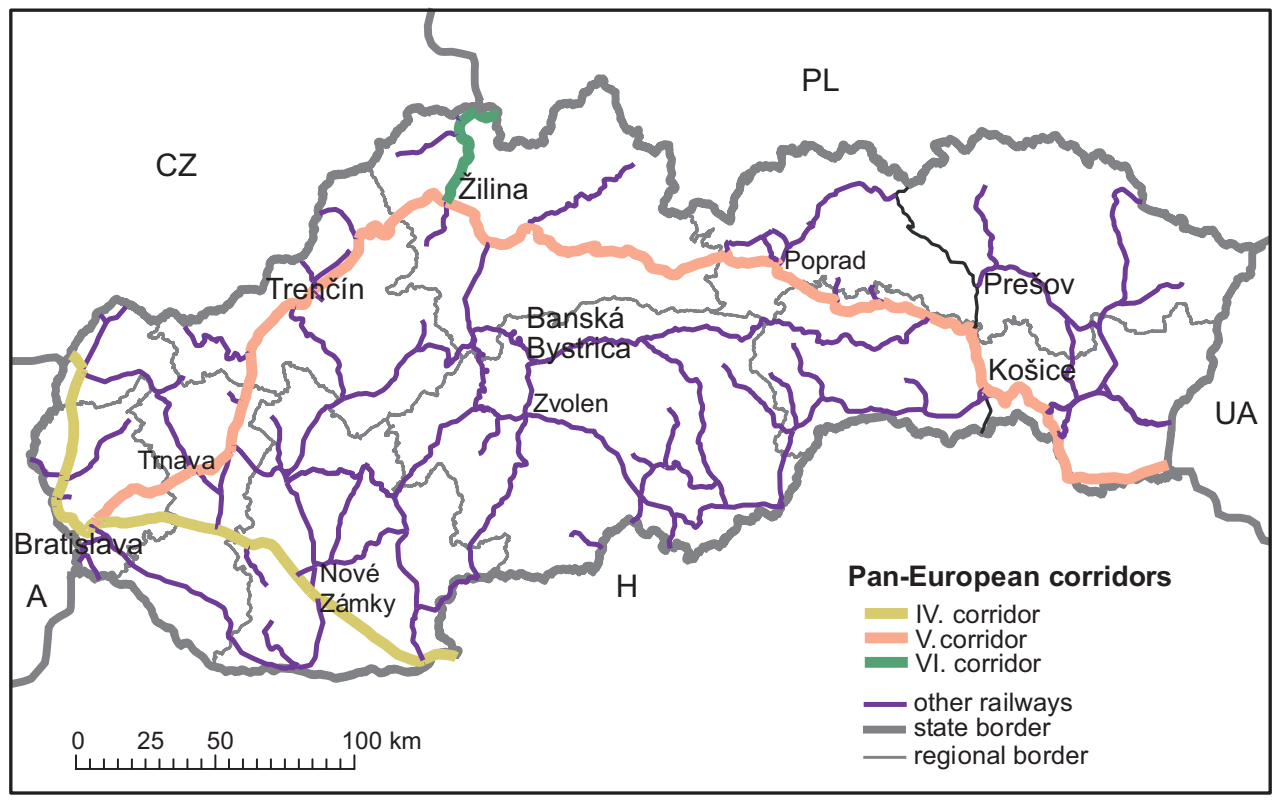

Figure 1. Railway network and Pan-European transport corridors in Slovakia

Table 1. Modernisation of railways in Slovakia for $160 \mathrm{~km} / \mathrm{h}$ speed

\begin{tabular}{|l|c|c|c|}
\hline \multicolumn{1}{|c|}{ Railway track } & Track No. & Period & Length [km] \\
\hline Bratislava-Rača - Nové Mesto nad Váhom & 120 & $2002-2009$ & 92 \\
Žilina - Krásno nad Kysucou & 127 & $2008-2011$ & 19 \\
Nové Mesto nad Váhom - Zlatovce & 120 & $2009-2013$ & 22 \\
Trenčianska Teplá - Ilava - Beluša - Púchov & 120 & $2009-2014$ & 27 \\
Zlatovce - Trenčianska Teplá & 120 & $2012-2016$ & 12 \\
\hline
\end{tabular}


priority projects No. 17 concerning the TransEuropean transport networks: the railway axis Paris-Strasbourg-Stuttgart-Vienna-Bratislava could be realistic. The prolongation of the broad-gauge track to Bratislava and Vienna is also being discussed albeit the question of profitability of such an investment has not yet been answered.

The transport of goods within an intermodal transport scheme is also one possible means of exploiting railways. But the Slovak Republic has no modern public intermodal transport terminals with the provision of services on a non-discriminatory basis in close relation to the logistics, which is a prerequisite for the participation of the SR in the open transport market within Europe and the world (OP Transport 2007). There are 7 container terminals in operation in Slovakia (Bratislava ÚNS, Bratislava-port, Košice, Žilina, Dobrá, Dunajská Streda and Sládkovičovo) operated by private companies.

A negative phenomenon that influences railway transport is the closure of passenger transport on several regional tracks. In total, passenger services were withdrawn on more than $530 \mathrm{~km}$ of railway tracks between 2000 and 2012. The southern part of the country was most affected by these measures (Fig. 2).

Regional railway closures bring immediate effect in the form of lowered operating costs. But other consequences of railway closures for passenger traffic can be dramatic for many inhabitants who are socially deprived and excluded, and these are not taken into account. The closure of regional railway passenger transport services affects commuting in the given region, the mobility of visitors and may negatively influence the further development of the region. This negative impact can be seen in the southern part of Central Slovakia which suffers from an unfavourable economic situation, low quality human potential, a high unemployment rate, poverty and also a reduction of regional railway transport. On the other hand the quality of passenger transport on the remaining regional tracks in Slovakia is gradually improving as 32 new regional train units were purchased with the help of EU funds within the Transport OP. In total 29 of these train units should be improving regional transport by 2015 .

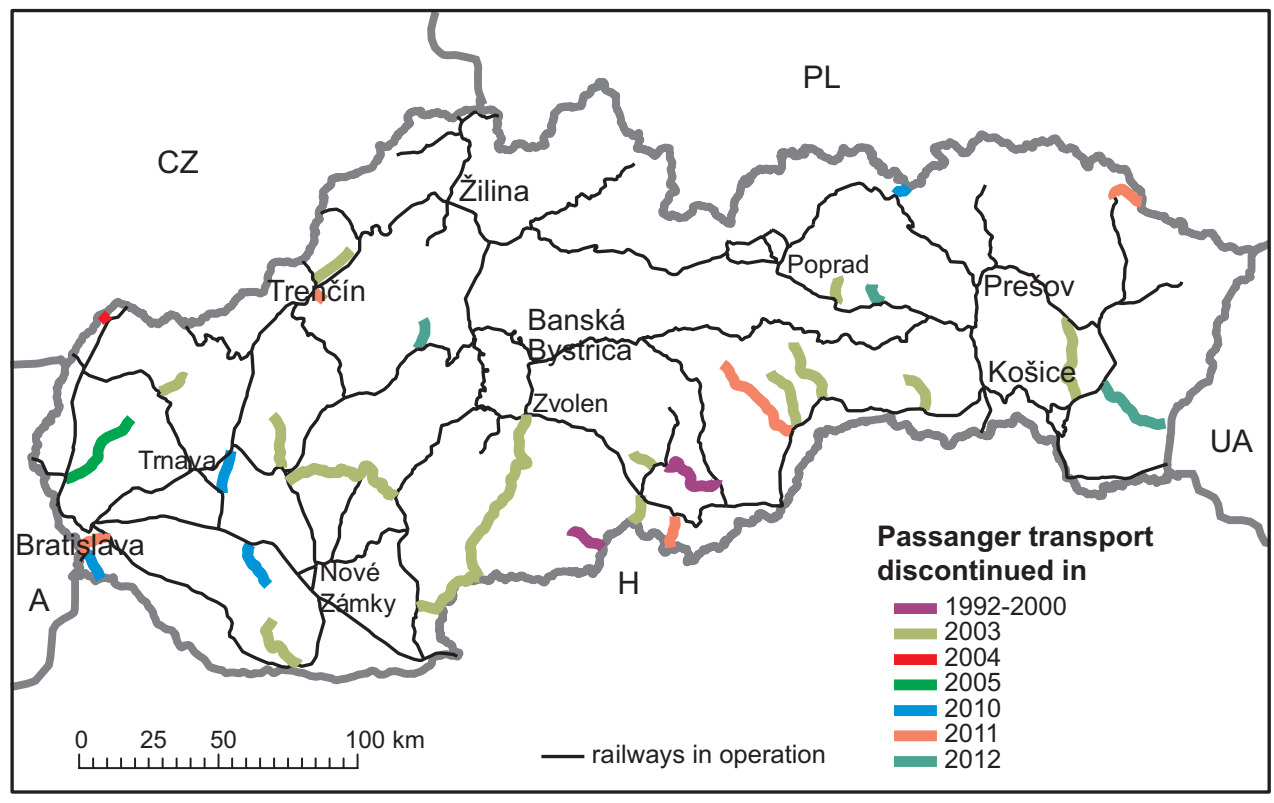

Figure 2. Railway closures after 1989 in Slovakia 


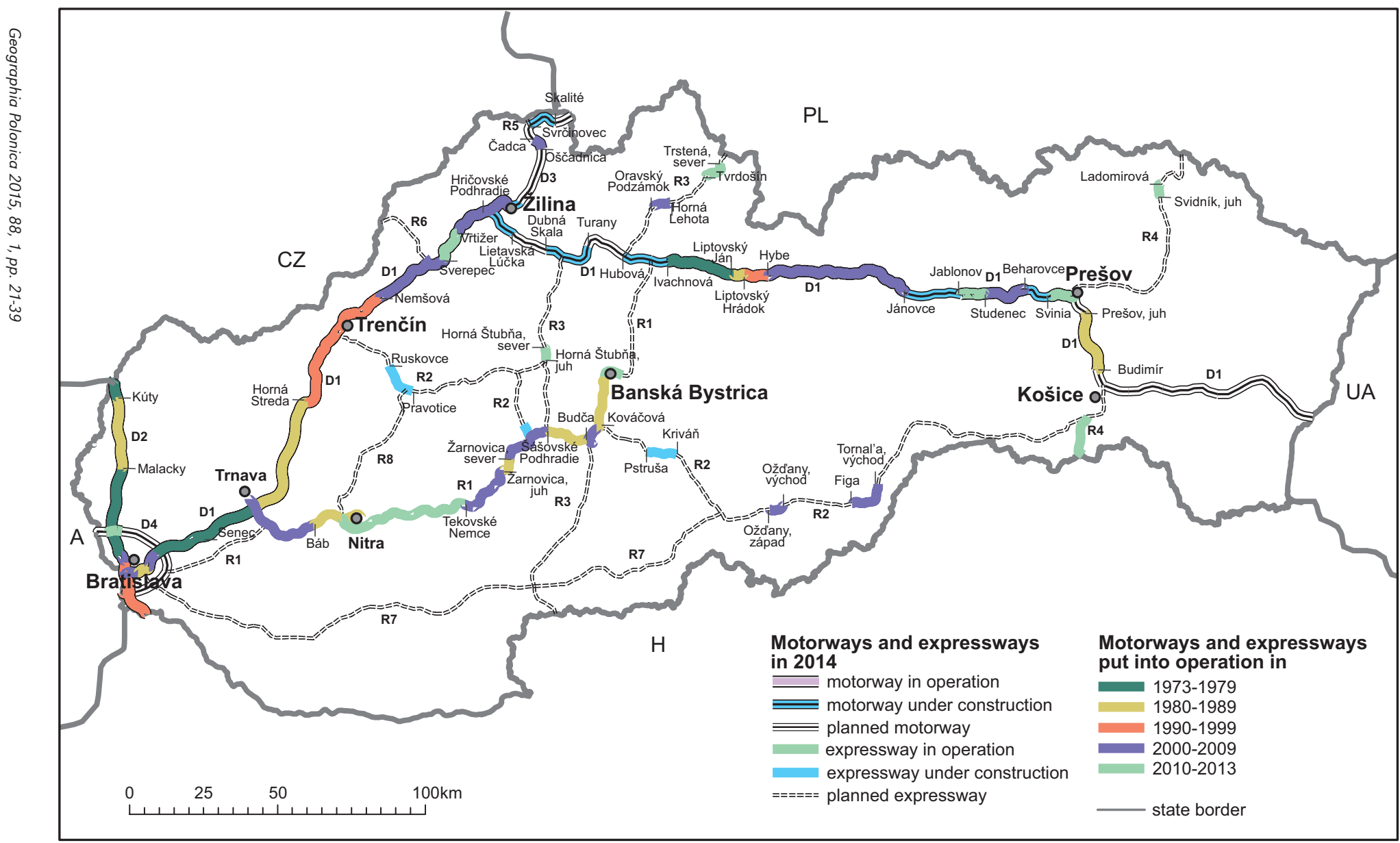

Figure 3. Development of the motorway and expressway network in Slovakia Source: based on data from NDS (2014). 


\section{Development of the motorway and expressway network}

The first proposals for the construction of motorways and expressways in Slovakia appeared in interwar Czechoslovakia. The proposed motorway routes were planned to run through the whole country in a west-east direction. Plans for the construction of motorways changed during World War II and also in the following periods. The construction of motorways in Slovakia started in 1969 with the building of the Brno - Bratislava section of the D2 motorway between Bratislava and Malacky. This motorway was supposed to provide for a road connection between the two most important centres of Czechoslovakia, Prague and Bratislava.

In 1976, construction started on the first sections of the present expressways near the important regional centres of Nitra and Banská Bystrica (then classified as 1st class roads). In the 1990s, the construction of the D1, D2 and D61 motorways continued (the common appelation D1 for the D1 and D61 motorways was introduced in 1999). The most intensive construction was in the period 2000-2009 with the focus on the D1 motorway, the most important road communication in Slovakia, part of the Pan European corridor Va and Trans-European Networks TEN-T (Baltic-Adriatic and Rhine-Danube corridors).

Figures 3 and 4 show the development of the motorway and expressway network in Slovakia and Table 2 describes the progress of construction of individual sections during recent decades.

In 2014, $320 \mathrm{~km}$ of D1 was in operation. The longest continuous part is the $187.6 \mathrm{~km}$ stretch between Bratislava and Hričovské Podhradie. In the north, $83.2 \mathrm{~km}$ of Ivachnová - Jánovce, 22.4 km of Jablonov - Fričovce with the Branisko tunnel, $7 \mathrm{~km}$ of Svinia - Prešov, in the west it is $19.1 \mathrm{~km}$ of Prešov South - Budimír. In 2015, the missing sections in the east, particularly Fričovce - Svinia $(11.2 \mathrm{~km})$, and Jánovce - Jablonov (18.5 km), should be finished. The most complicated is the construction of the D1 section Hričovské Podhradie - Ivachnová, which runs in mountainous landscape with protected areas including the $7.5 \mathrm{~km}$ long Višňové tunnel. The deadline for the conclusion of the continuous D1 motorway Bratislava - Košice is being repeatedly put off and it is now expected in 2020. The D1 motorway is to continue as far as the Ukrainian border with its overall length amounting to $516.4 \mathrm{~km}$.

The D2 motorway connecting the SK/CZ border (locality Kúty) and the SK/HU border (locality Čunovo) has been finished in its full profile and $80 \mathrm{~km}$ length. The last section in Bratislava (Lamačská cesta - Staré Grunty) with the Sitina tunnel was finished in 2007. The D2 is included into the Pan-European corridor IV and the trans-European transport networks TEN-T.

The D3 motorway passes through northwestern Slovakia and connects the D1 motorway (Hričovské Podhradie) with the SK/PL border (Skalité). The Hričovské Podhradie - Žilina section of the D3 motorway is part of the Pan European corridor $\mathrm{Va}$ and the section between Žilina - and the SK/PL border (Skalité) is part of the Pan-European corridor VI. The overall length of the finished motorway will be $59.8 \mathrm{~km}$.

The D4 motorway is planned as a $50 \mathrm{~km}$ outer motorway bypass of Bratislava. Nowadays, only a small section from the border crossing SK/AT Jarovce to the D2 Jarovce and a half-profile section acting as a motorway

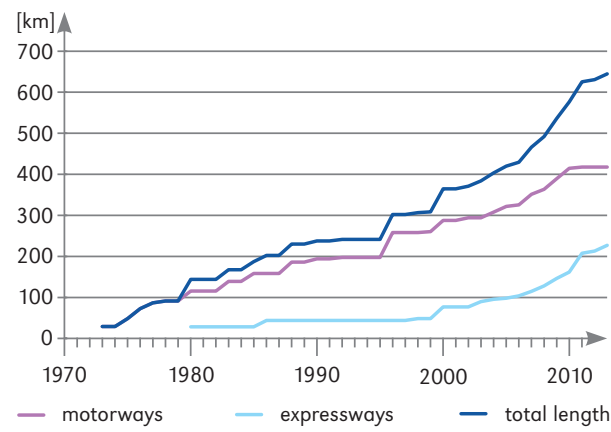

Figure 4. Development of the length of the motorway and expressway network in Slovakia since 1970

Source: Own analysis based on data from NDS (2014). 
Table 2. Progress of construction of individual sections of the motorway and expressway network in Slovakia

\begin{tabular}{|c|c|c|}
\hline Period & Sections & Length [m] \\
\hline \multirow[t]{2}{*}{ 1970-1979 } & $\begin{array}{l}\text { D1 Senec - Trnava (1975); Bratislava, Senecká cesta - Senec (1976); Liptovský } \\
\text { Mikuláš - Liptovský Ján (1976); Ivachnová - Liptovský Mikuláš (1977) }\end{array}$ & 57,568 \\
\hline & $\begin{array}{l}\text { D2 Malacky - Bratislava, Lamačská cesta (1973); state border SK/CZ (Brodské) } \\
\text { - Kúty (1978) }\end{array}$ & 33,825 \\
\hline \multirow[t]{3}{*}{ 1980-1989 } & $\begin{array}{l}\text { D1 Trnava - Hlohovec (1983); Liptovský Ján - Liptovský Hrádok (1983); Brati- } \\
\text { slava, Prístavný most (1985); Bratislava, Prístavný most - Bratislava, Mierová } \\
\text { ulica (1985); Hlohovec - Pieštany (1985); Pieštany - Horná Streda (1988); Prešov, } \\
\text { south - Budimír (1988) }\end{array}$ & 70,501 \\
\hline & D2 Kúty - Malacky (1980) & 24,175 \\
\hline & $\begin{array}{l}\text { R1 Báb - Nitra (1980); Kováčová - Banská Bystrica, west (1980); Šášovské } \\
\text { Podhradie - Budča (1986) }\end{array}$ & 43,870 \\
\hline \multirow[t]{4}{*}{ 1990-1999 } & $\begin{array}{l}\text { D1 Liptovský Hrádok - Hybe (1990); Horná Streda - Nové Mesto nad Váhom } \\
\text { (1996); Nové Mesto nad Váhom - Chocholná (1996); Chocholná - Skala (1996); } \\
\text { Skala - Nemšová (1996) }\end{array}$ & 53,770 \\
\hline & $\begin{array}{l}\text { D2 Bratislava, Staré Grunty - Bratislava, Viedenská cesta (1992); Bratislava, } \\
\text { Viedenská cesta - state border SK/HU (Čunovo) (1996) }\end{array}$ & 18,390 \\
\hline & $\begin{array}{l}\text { D4 state border SK/AT (Jarovce) - Bratislava, Jarovce (intersection with the D2) } \\
\text { (1999) }\end{array}$ & 2,000 \\
\hline & R1 Žarnovica, juh - Žarnovica, north (Žarnovica, bypass) (1998) & 4,470 \\
\hline \multirow[t]{7}{*}{$2000-2009$} & $\begin{array}{l}\text { D1 Nemšová - Ladce (2000); Hybe - Važec (2000); Bratislava, Mierová ulica - } \\
\text { Bratislava, Senecká cesta (2002); Beharovce - Fričovce (2004); Ladce - Sverepec } \\
\text { (2005); Bratislava, Viedenská cesta (intersection with the D2) - Bratislava, } \\
\text { Prístavný most (2006); Vrtižer - Hričovské Podhradie (2007); Važec - Mengus- } \\
\text { ovce (2008); Mengusovce - Jánovce (2009) }\end{array}$ & 113,057 \\
\hline & D2 Bratislava, Lamačská cesta - Bratislava, Staré Grunty (2007) & 3,661 \\
\hline & $\begin{array}{l}\text { D3 Oščadnica - Čadca, Bukov (Čadca, bypass) (2005); Hričovské Podhradie } \\
\text { (križovatka D1) - Žilina, Strážov (2007) }\end{array}$ & 12,479 \\
\hline & $\begin{array}{l}\text { R1 Trnava - Báb (2000); Hronský Beňadik - Rudno nad Hronom (2003); Budča } \\
\text { - Kováčová (2004); Tekovské Nemce - Hronský Beňadik (2005); Rudno nad } \\
\text { Hronom - Žarnovica, south (2006); Žarnovica, north - Śášovské Podhradie } \\
\text { (2009) }\end{array}$ & 70,681 \\
\hline & $\begin{array}{l}\text { R2 Ožd'any, west - Ožd'any, east (Ožd'any, bypass) (2007); Figa, west - Figa, east } \\
\text { (Figa, bypass) (2008); Figa, east - Tornal'a (Tornal'a, bypass) (2008) }\end{array}$ & 18,169 \\
\hline & R3 Horná Lehota - Oravský Podzámok (2007) & 6,442 \\
\hline & R6 Dolné Kočkovce - Beluša (intersection with the D1) (2004) & 2,681 \\
\hline \multirow[t]{5}{*}{$2010-2014$} & $\begin{array}{l}\text { D1 Sverepec - Vrtižer (2010); Jablonov - Studenec (2010); Studenec - Beharovce } \\
\text { (2010); Svinia - Prešov, west (2010) }\end{array}$ & 25,203 \\
\hline & D4 Bratislava, Záhorská Bystrica - Bratislava, Devínska Nová Ves (2011) & 3,025 \\
\hline & $\begin{array}{l}\text { R1 Nitra, west - Selenec (2011); Selenec - Beladice (2011); Beladice - Tekovské } \\
\text { Nemce (2011); Banská Bystrica, west - Banská Bystrica, north (Banská Bystrica, } \\
\text { northern bypass) (2012) }\end{array}$ & 51,006 \\
\hline & $\begin{array}{l}\text { R3 Trstená, north - Tvrdošín (Trstená, bypass) (2010) ; Horná Štubňa, north - } \\
\text { Horná Štubňa, south (Horná Śtubňa, bypass) (2010) }\end{array}$ & 11,037 \\
\hline & $\begin{array}{l}\text { R4 Ladomirová - Svidník, south (Svidník, bypass) (2010); Košice - state border } \\
\text { SK/HU (Milhost') (2013) }\end{array}$ & 18,773 \\
\hline
\end{tabular}

Source: NDS (2014). 
feeder of the D2 motorway from Stupava to Devínska Nová Ves is in operation.

The most important expressway is the R1 with a continuous $170 \mathrm{~km}$ section already finished. The sections between Nitra and Tekovské Nemce and the bypass of Banská Bystrica were built as part of what is referred to as the second packet of PPP (Public Private Partnership) projects, which is the only PPP transport infrastructure project concluded in Slovakia. Since 2009, the extension of the R1 expressway from Banská Bystrica over the Low Tatra Mts. to Ružomberok and a connection with the D1 motorway is being considered. As far as other planned expressways are concerned, before the end of 2013 only short and mostly half-profile sections have been finished. Due to problems with the D1, construction of this section would make possible an earlier conclusion of the motorway connection between the two biggest cities in Slovakia, Bratislava and Košice. Only a few EU countries (Latvia, Estonia, Poland and Romania) have no motorway or expressway connection between their two biggest cities.

Slovakia belongs to those countries with the lowest density of motorways and expressways in the EU $\left(12.9 \mathrm{~km} /\right.$ thousand $\mathrm{km}^{2}$ in 2014). Only a third $(644.8 \mathrm{~km})$ of the planned motorway and expressway network $(1,868 \mathrm{~km})$ was in operation in 2014 (Fig. 3).

Future development of the motorway and expressway network in less developed regions can bring them faster and economically advantageous connections with other regions of Slovakia and neighbouring countries and would open possibilities for investment in these regions. Currently only south-west Slovakia is connected to the motorway network in neighbouring countries though its connection with the Czech Republic and Hungary by the D2 motorway and with Austria by the D4 motorway. There is also a motorway connection to the border with Hungary in eastern Slovakia (the R4 section Košice Milhost'), but the nearest motorway in Hungary begins in Miskolc (57 km from the border).

Development of road infrastructure depends on the amount of expenditure on road infrastructure (Fig. 5). In 2000-2005 this was

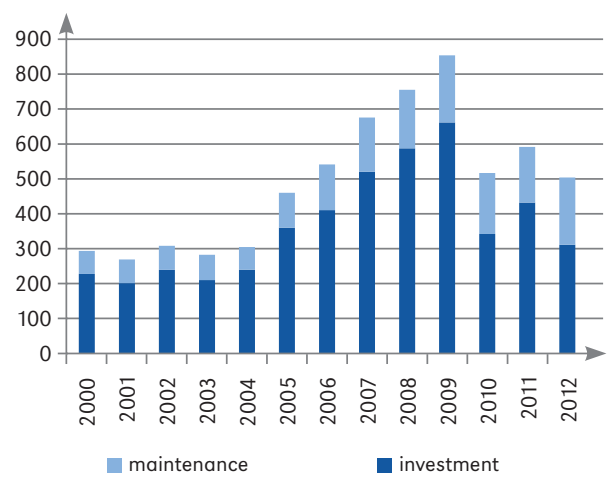

Figure 5. Total expenditure on road infrastructure (current prices in million euros)

Source: based on the data of the MDVRR SR (2014).

around $€ 300$ million per year. Later, in the period of economic growth up to 2009, this amounted to almost $€ 850$ million. After 2009, expenditure connected with road infrastructure dropped due to the economic crisis and the subsequent cancelling of two pre-prepared PPP projects for the construction of the D1 motorway after a change in the Slovak government, in 2010. Investments in road infrastructure, with the exception of years 2010 and 2012, represent about $3 / 4$ of total expenditures on road infrastructure ( $1 / 4$ of expenditures is allocated to the maintenance of road infrastructure).

For detailed information concerning the development of transport infrastructure and the conditions of its development in Slovakia see e.g. Podhorský (1974), Korec (1984), Lukniš (1985), Kubáček (1999) and Horňák (2006). Podhorský (1974) described transport and transport infrastructure and their development in Slovakia. Korec (1984) focused on geographical aspects of the development of road transport in Slovakia. Lukniš (1985) analysed the primary potential of regions in Slovakia, which consists of their location and natural potential and influences the regional structure of Slovakia. Kubáček (1999) described the history of railways in Slovakia and Horňák (2006) studied transport infrastructure from the point of view of analysis of the regional development context in the pre-transformation period. 


\section{Impact of transport infrastructure on travel time}

Improvement of transport infrastructure leads to a reduction of travel times and/or transportation costs. Construction of a new transport infrastructure (motorways and expressways) or modernisation of railway tracks in Slovakia may bring a reduction in the physical distance between the starting and final points of routes. Better transport parameters on motorways and modernised railways make the transport faster and save time, which may bring cost savings in personal transport and transport of goods. This fact can be illustrated by the changed transport time on the Žilina - Bratislava route. While in 1974 a journey by fast train took 180 min (ČSD 1974) now it is $166 \mathrm{~min}$ and by IC trains only $132 \mathrm{~min}$ (CP 2014). Reduction of time distance on this route due to the track upgrading is more conspicuous in the case of IC trains because only train units of this category are able to exploit the $160 \mathrm{~km} / \mathrm{h}$ speed and these trains only stop at selected stations. Compared with individual car transport, the journey on the same Žilina - Bratislava route in 1974 took around 180-190 min (similar to the contemporary train). The journey on the newly built motorway between Bratislava and Žilina by passenger car takes about 104 min (Google Maps 2014). The reduction in the time distance is considerable and it accelerates transportation. This time reduction is smaller in case of freight transport because of a smaller difference between the maximum speeds of a lorry on motorways and 1st class roads than the difference between the maximum speeds of a car.

The importance of the shortening of the railway travel time distance for regional development in Slovakia is limited because of the small spatial extent of regions with improved railway accessibility. In the future this situation will mainly change on the Košice - Žilina - Bratislava line. According to Závodský(2008), who studied the influence of the modernisation of railways on average transport speed, the average time distance between Bratislava and Košice will be reduced by 114 min to 4.5 hours and the average speed will increase by almost $30 \mathrm{~km} / \mathrm{h}$ to $97.6 \mathrm{~km} / \mathrm{h}$.

The construction of new motorways and expressways also brings a shortening of time distance and huge savings in time (Tab. 3 and 4).

Newly constructed or planned motorway and expressway sections eliminate the problems caused by driving through towns and by transport bottlenecks as e.g. a section of the D1 motorway should eliminate transport problems in Žilina and problems with the transport bottleneck between Strečno and Vrútky. Maximum time savings on selected sections reach between $40-59 \%$.

Average travel time on the D1 motorway between Bratislava and Košice is currently

Table 3. Time savings on selected motorway and expressway sections

\begin{tabular}{|c|c|c|c|c|c|}
\hline \multirow{2}{*}{$\begin{array}{l}\text { Motorway or expressway } \\
\text { section }\end{array}$} & \multicolumn{2}{|c|}{ Road distance [km] } & \multicolumn{2}{|c|}{ Time distance [min] } & \multirow{2}{*}{$\begin{array}{c}\text { time savings } \\
{[\%]}\end{array}$} \\
\hline & $\begin{array}{c}\text { before } \\
\text { construction }\end{array}$ & $\begin{array}{c}\text { after } \\
\text { construction }\end{array}$ & $\begin{array}{c}\text { before } \\
\text { construction }\end{array}$ & $\begin{array}{c}\text { after } \\
\text { construction }\end{array}$ & \\
\hline D1 Sverepec - Vrtižer & 12.9 & 9.6 & 12 & 5 & 58.3 \\
\hline $\begin{array}{l}\text { D1 Hričovské Podhradie - } \\
\text { Dubná Skala }\end{array}$ & 33.1 & 24.8 & 25 & 12 & 52.0 \\
\hline D1 Jánovce - Jablonov & 23.0 & 18.5 & 19 & 9 & 52.6 \\
\hline D3 Žilina, Strážov - Skalité & 51.9 & 51.4 & 52 & 24 & 53.8 \\
\hline $\begin{array}{l}\text { R1 Nitra, west - Tekovské } \\
\text { Nemce }\end{array}$ & 46.0 & 45.8 & 35 & 21 & 40.0 \\
\hline
\end{tabular}

Source: based on NDS (2014) and Google Maps (2014) data. 
Table 4. Expected time savings on the D1 motorway [min]

\begin{tabular}{|l|c|c|}
\hline \multicolumn{1}{|c|}{ Motorway D1 section } & Passenger transport & Freight transport \\
\hline Hričovské Podhradie - Lietavská Lúčka & 8.2 & 7.7 \\
Lietavská Lúčka - Višňové - Dubná Skala & 14.2 & 14.6 \\
Dubná Skala - Turany & 11.4 & 10.1 \\
Turany - Hubová & 6.8 & 6.4 \\
Hubová - Ivachnová & 9.5 & 10.3 \\
Jánovce - Jablonov & 11.1 & 8.9 \\
Fričovce - Svinia & 3.8 & 2.5 \\
Prešov bypass & 8.3 & 7.2 \\
\hline Total & 73.3 & 67.7 \\
\hline
\end{tabular}

Source: Krajanová (2014) based on data from the Transport Research Institute in Žilina.

4 hours and 50 min. After all the missing sections have been completed the travel time savings for individual passengers will be over $73 \mathrm{~min}$ and for freight over 67 min (Krajanová 2014).

In many situations there can also be negative influences of transport on travel time. Exceeding an insufficient transport capacity of infrastructure due to increased mobility can cause traffic jams and the estimated travel time increases.

\section{Impact of transport infrastructure on the location of industrial investment}

After 1989, the very poor state of transport infrastructure in Eastern and Central European countries was one important obstacle to their integration in the world economy. Martin and Rogers (1995) examined the impact of public infrastructure on industrial location and arrived at the conclusion that regional policies which focus on the financing of domestic infrastructure in a poor country lead firms to relocate in this country. On the other hand, regional policies, which finance international or transit oriented infrastructure in a poor country, will lead firms to relocate their production to another country. According to Holl (2004), who analysed the impacts of road transport infrastructure on manufacturing location in Spain, firms prefer locations closer to new motorways at the cost of more distant municipalities.

A good quality transport infrastructure may lead to the geographical specialisation of a region in the production of certain goods or services for which this region has better conditions compared to other regions. Such specialisation supports the increase of productivity and development of spatial relationships between companies. An efficiently working transport system supports the development of mass production (Rodrigue et al. 2013). The development of the automotive industry in Slovakia is a good example.

Jakubiak et al. (2008) analysed automotive investment in the Slovak Republic and also discussed the motivations for automotive investment. Until 1997 the Slovak Republic was regarded as a regional laggard in the implementation of reform and economic performance. After the 1998 elections, the government coalition started the implementation of reforms (efforts in promoting privatisation, corporate restructuring, improvement of public service delivery, reforms of pensions and taxes, the labour code, social protection, and health care). Strong implementation, a commitment to reforms and favourable initial conditions (tradition in the automotive sector and other heavy industry sectors, skilled labour) have played a crucial role in attracting automotive investments. The EU accession process 
supported by strong political consensus and the boosting of living standards played an important role in the reform process. Generous investment incentives provided by the Slovak government helped sway foreign investors in selecting the Slovak Republic within the broader region of central Europe.

There are three major car-manufacturing investments in Slovakia: Volkswagen in Bratislava (from 1991), PSA Peugeot Citroën in Trnava (from 2003) and Kia Motors in Žilina (from 2004). Volkswagen is a brownfield investment, later extended, in the facilities of the former BAZ company located in the periphery of Bratislava. Besides Bratislava there are also Volkswagen subsidiaries in Martin and Košice. PSA Peugeot Citroën in Trnava and Kia Motors in Zilina are greenfield investments. The reasons for the selection of Trnava were the advantageous geographical position and proximity to large markets, a skilled labour force, the railway and motorway accessibility of the locality and the country's tradition in car manufacturing. Factors that influenced the selection of Žilina included
English-language education for employees' children; a hospital; support by the Technical University in Žilina specialised in transport; construction of a railway terminal; the promise of completion of the motorway to Žilina and a reconstruction of the nearby airport in Dolný Hričov (Jakubiak et al. 2008). The selection of Trnava and Žlina as the localities for new investment in the automotive industry was to a large extent influenced by good transport infrastructure and accessibility (railway network and motorway D1).

Investment in automotive production contributed to additional investment by suppliers that has helped generate locally owned suppliers (Jakubiak et al. 2008). It contributes to the growth of employment and the overall development of regions. The three car producers in Slovakia employ more than 16 thousand employees and in 2013 produced 988 thousand cars. The automotive industry in Slovakia is concentrated in the western part of the country (Fig. 6). Currently, 274 production plants supplying the automotive industry operate in Slovakia. These include 202 located

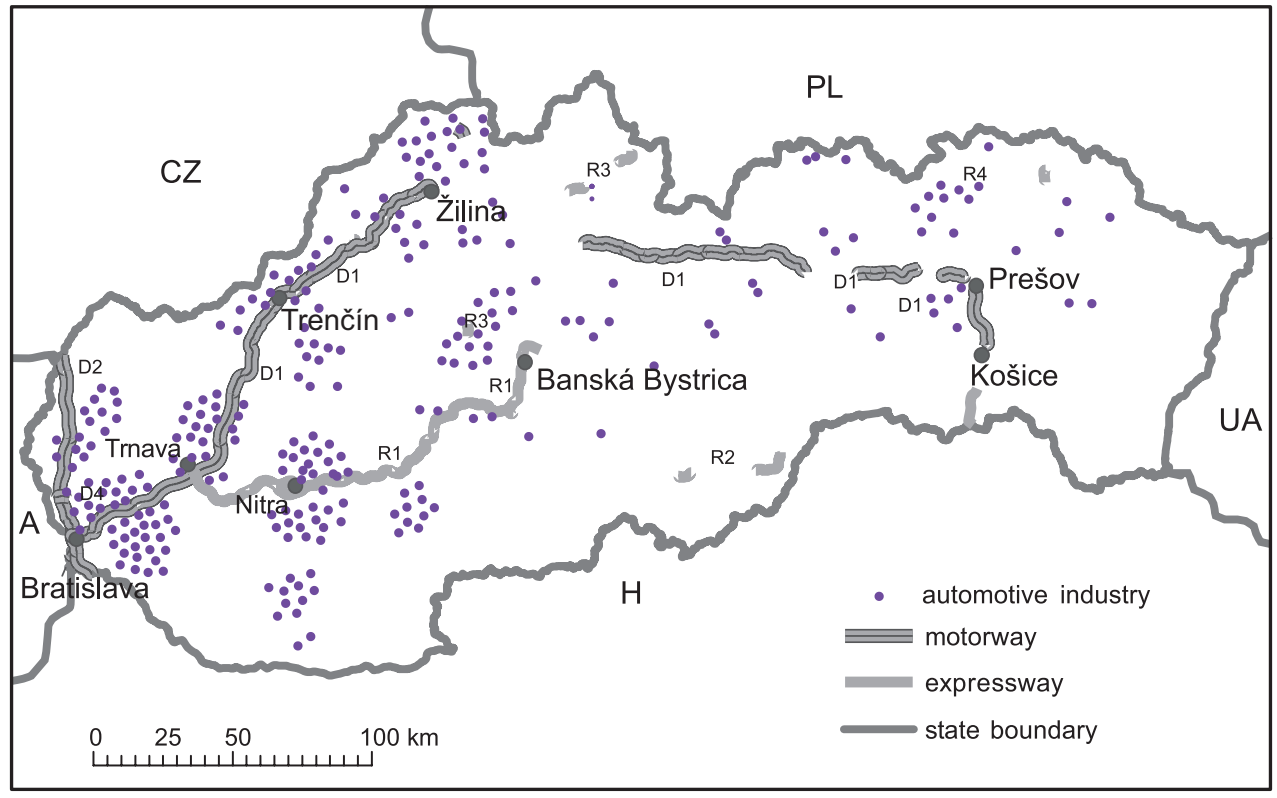

Figure 6. Location of production plants supplying the automotive industry in Slovakia Source: adjusted according to SARIO (2012). 
in the western of the country especially along the motorway D1 from Bratislava to Žilina and the expressway R1 from Trnava to Banská Bystrica (SARIO 2012).

Another example is the electrical engineering industry, which is an important pillar of the Slovak economy in addition to the automotive industry. The biggest investors located their companies in the western part of Slovakia with good transport accessibility, e.g. the biggest company in the electrical engineering industry, Samsung, has its production plants in Galanta and Voderady, Foxconn has its plant in Nitra, and Emerson in Nové Mesto nad Váhom (Fig. 7). But there are also important electrical engineering companies in other parts of Slovakia e.g. Whirlpool in Poprad, BHS Drives and Pumps in Michalovce, Panasonic in Krompachy and Trstená. This industrial branch is based on a long-term tradition in electrical engineering production, which started in the era of socialism, and on the educated labour force. Kulla (2013) analysed the present state and trends in the electrical engineering industry in Slovakia.
An efficient transport system contributed to the competitiveness of products and services. Missing connections in the transport network represent an important barrier to the potential productivity of a region (Rietveld \& Nijkamp 1992). Logistics centres provide suitable conditions for goods based connections between industrial and commercial companies. Logistics centres and parks in Slovakia are very unevenly distributed and they are mostly located in south-western Slovakia. According to Kubasáková (2011), 81.39\% of all logistics facilities in Slovakia are located in the Bratislava and Trnava regions. This is due to the good transport connections in this area, its good accessibility to industrial centres (especially in the automotive and electrical engineering industry) and the good accessibility of the neighbouring countries and other European countries, which represent the market area for the industrial products from Slovakia.

However, investments in infrastructure do not automatically lead to an increased economic performance of the region (Vickerman 1996). The new infrastructure is often

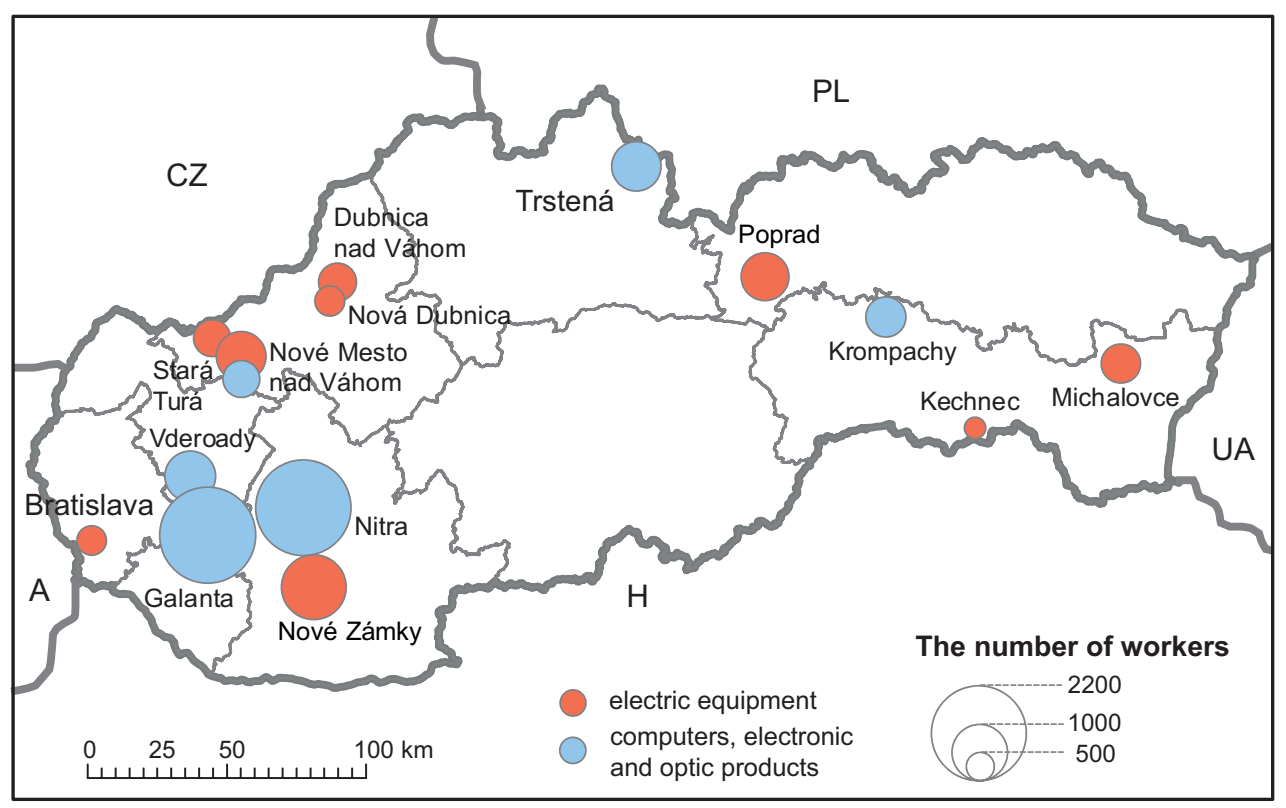

Figure 7. Location of the largest electrical engineering companies in Slovakia Source: adjusted according to Kulla (2013), based on data from Trend Top 2012. 
built between the core regions or within them where the demand of transport is highest. The construction of connections between important centres and the periphery can lead to an increase of already existing differences in accessibility between regions (Vickerman et al. 1999), because apart from the improved accessibility of the periphery the accessibility of the core region also improves. A possible result is also an increase in regional disparities between the cores and the peripheral regions.

\section{Other impacts of investment in transport infrastructure}

The importance of transport, transport infrastructure and transport accessibility can also be seen in the tourism sector. The capacity and arrangement of transport infrastructure are key elements in the determination of accessibility (Rodrigue et al. 2013). Transport is an integral part of many tourism activities. Transport enables connections to be made between the source markets of tourists and the destinations visited, provides mobility and access within a destination area/region/ country and within an actual tourism attraction and facilitates travel along a recreational route which is itself the tourism experience (Hall 1999). Improvement of transport infrastructures leads to a decrease in time or costs of travel. This means that a tourist can make a longer journey within the same threshold of time/costs, or that a destination is accessible by tourists within a larger area thus expanding its tourist market.

Transport infrastructure may influence the development of the regions it crosses but its effects may also appear in other regions. The benefits to other regions of investments in transport infrastructure can be observed via, for instance, the changed accessibility of regions where no investments were put. Więckowski et al. (2012) analysed inter alia the impact of the construction of the officially planned network of motorways and expressways in the period 2010-2030 on tourism development in the Polish-Slovak borderland using the potential accessibility approach. The infrastructure construction contributes to the growth of the number of potential tourists that can reach this tourist region in a specific travel time. They concluded that the development of the network of motorways and expressways in the Polish-Slovak borderland would lead to intensification of the weekend tourism or short stay tourism trade.

Among the positive effects of motorway and expressway construction is the reduction in traffic accidents. These roads are normally safer that 1 st class roads. For instance, in 2012-2013 no fatal accident occurred on certain sections of the R1 built under the PPP project (PR1BINA 2014), while before its construction the Nitra - Zlaté Moravce road was one of the most dangerous in Slovakia. It should be admitted though that the consequences of accidents on motorways are worse because of the higher speed. Road transport is also the least safe of all types of transport. The number of accidents on roads is higher than on railways and other types of transport and passenger safety is under threat in each road accident. An overview of data about transport accidents on Slovak motorways in 2006-2013 is presented in Table 5.

Table 5. Transport accidents on Slovak motorways in 2006-2013

\begin{tabular}{|l|r|r|r|r|r|r|r|r|}
\hline \multicolumn{1}{|c|}{ Number of } & 2006 & 2007 & 2008 & 2009 & 2010 & 2011 & 2012 & 2013 \\
\hline Accidents & 1,341 & 1,517 & 1,439 & 848 & 746 & 405 & 430 & 449 \\
Killed & 15 & 19 & 13 & 9 & 13 & 8 & 5 & 5 \\
Seriously injured & 42 & 32 & 24 & 27 & 32 & 28 & 27 & 23 \\
Slightly injured & 166 & 128 & 130 & 121 & 138 & 103 & 130 & 115 \\
\hline
\end{tabular}

Source: MINV SR (2014). 
There is an obvious tendency for a decrease in negative phenomena that are connected with accidents on motorways in spite of the construction of new sections.

The effects of motorways on the environment can be both positive and negative. They can mitigate some negative effects such as noise or dust on the living environment of humans e.g. by shifting transit from existing roads in built-up areas to motorways and expressways. One of negative effects connected with the construction of transport infrastructure is soil sealing. Rare biotopes can also be damaged by construction and the motorway is also a barrier to the movement of animals. There are often conflicts between the construction of transport infrastructure and environmental protection. The Turany - Hubová section of the D1 motorway is a good example. There was no variant of the D1 motorway, which would not come in direct physical conflict with Natura 2000 sites. The process of evaluation of the effects of the Turany - Hubová section of the D1 motorway on the Natura 2000 network slowed the preparation for its construction. A landslide in 2013 postponed the beginning of construction of the selected variant, and the construction of two alternatives is being reconsidered. This section is problematic and it will probably be the last section of the D1 motorway between Bratislava and Košice to be constructed. In a few years' time there will probably be a transport bottleneck similar to the recent bottleneck between Strečno and Vrútky.

The short-term effects of the construction of motorways and expressways include increased employment in the region. New jobs in the maintenance of roads after they are finished are also offered. Motorways have a positive indirect influence on employment by the creation of jobs in companies that have emerged in localities with good transport accessibility. A quality transport infrastructure also means increased labour mobility and increased physical distance for commuters due to improved time distance. As transport journey times and/or costs fall with new transport systems, labour markets expand as workers are prepared to travel a longer distance within the same overall commuting time and cost threshold, so that catchment areas widen (SACTRA 1999; Knowles \& Ferbrache 2014). On the other hand, better accessibility contributes to the migration of educated population groups from the country's periphery to bigger towns and their suburbs.

The construction of motorways and expressways may also change the price of real estate. Plots with good transport accessibility in the vicinity of important road junctions (e.g. motorway intersections) often provide better opportunities for expansion and are ideal for the location of large logistics centres, industrial parks, shopping centres, etc. On the other hand, grounds near motorways or an airport are not suitable for residential areas because of noise and air pollution. New motorway connections can also contribute to a rise of the attractiveness of some localities (mainly in rural areas) as a place to live because of their better accessibility to towns and cities.

However, exceeding insufficient capacity on the transport infrastructure causes traffic jams in big cities and their environs in peak hours. It is at this time that some advantages of the motorway change into disadvantages. The presumed transport cost and travel time, as well as the environmental load attributable to transport increase. Besides exceeding the capacity of the transport infrastructure, the existence of transport bottlenecks is an additional factor that can hinder the development of a region.

\section{Discussion and conclusions}

This article deals with the development of transport infrastructure in Slovakia and its impacts on travel time and in particular on the location of industrial investment. Other impacts of investment in the transport infrastructure (on tourism, traffic accidents, the environment, employment, and the price of property) are also outlined. Transport infrastructure, and related transport accessibility, is one of the most important conditions for the 
economic development of a region. The good accessibility of the region can help to attract investors who create new jobs. In accordance with Holl (2004) better transport connections can make areas of lower economic activity more attractive for the location of firms as they gain better access to markets in the core areas. Transport accessibility can benefit the majority of economic sectors. Transport infrastructure was a decisive factor affecting the location in Slovakia of investments by companies in the automotive and electrical engineering industries and of logistics centres. Industrial investment brought new workplaces and contributed to the improvement of the economic situation of some regions.

Investment in transport infrastructure in Slovakia after 1989 mainly focused on motorway and expressway construction and the modernisation of railway infrastructure. Motorways and expressways in Slovakia were built in corridors along the line of the biggest existing and planned demand for transport. The pattern of the motorway network reflects the regional structure of Slovakia divided into the more advanced north-western part and the lagging south-eastern part.

The motorway network in south central, the north-east and south eastern Slovakia (with the exception of the Košice region) is deficient. These regions are the ones with a higher unemployment rate, lower average wages, greatest rates of poverty and an insufficient influx of investment (see e.g. Michálek 2004; Korec \& Ondoš 2009; Michálek \& Veselovská 2014; Michálek et al. in press). However, the absent transport infrastructure is not the only factor behind this unfavourable economic situation. The bad educational and social structure of the population, scarce offers of jobs, and the emigration of educated people to other regions and abroad are important additional factors. Fragmented self-government (the existence of many small communes as the smallest territorial and administrative units in Slovakia) also contributes to this adverse situation.

The construction of transport infrastructure in Slovakia concentrates mainly in the more developed part of Slovakia and it contributes rather to increase regional disparities. Future development of the motorway and expressway network in less developed regions can improve accessibility (via bringing them faster and economically advantageous connections with other regions of Slovakia and neighbouring countries) and can open investment possibilities in these regions. However, when the transport infrastructure in these regions is built (after 2020), there will be a loss or decline of other competitive advantages in comparison with other countries, including, in particular, a cheap and educated labour force. These regions are likely to continue to lag behind and regional disparities will continue to deepen. Investments in the transport infrastructure in Slovakia rather contribute to the growth of regional disparities. Halás (2005), who was involved in the transport potential of regions in Slovakia, arrived at a similar conclusion and pointed to the deepening regional disparities in transformation period.

Investment in modernisation of the railway infrastructure (increase in the speed limit to $160 \mathrm{~km} / \mathrm{h}$ ) concentrates on the western part of Slovakia and its effects on regional development are not visible because of their small spatial extent and small overall time savings. There is an unexploited potential for the development of intermodal transport of goods in Slovakia. Closures of passenger transport on several regional railway routes affect the population's mobility (commuting and visiting rate of the regions concerned) with a negative impact on the overall development of such regions.

However, the building of transport infrastructure (motorway and expressway network) is financially very demanding. The financial resources of EU Funds (in addition to the complexities involved in their acquisition) and the state budget destined to fund transport infrastructure are not sufficient. This is the reason why the construction of motorways in Slovakia is constantly put off and delayed. The modernisation of railways also progresses very slowly. The EU Funds in the Programming 
period 2014-2020 will be an important tool for the development of transport infrastructure in Slovakia.

Investment in the transport infrastructure (motorway and expressway network, modernisation of railways) can have positive impacts on regions in Slovakia. However, transport infrastructure alone is unlikely to be a sufficient catalyst for economic change without other supportive policies (Knowles \& Ferbrache 2014). Infrastructure provision is, however, only a proxy for accessibility, which is only a proxy for the transport cost incurred in a region on the assumption that firms will be able to exploit changes in accessibility in increasing competitiveness, leading

\section{References}

Albarran P., Carrasco R., Holl A., 2013. Domestic transport infrastructure and firms' export market participation. Small Business Economics, vol. 40, no. 4, pp. 879-898.

Banerjee A., Duflo E., QIAN N., 2012. On the road: Access to transportation infrastructure and economic growth in China. NBER Working Paper Series, no. 17897, Cambridge: National Bureau of Economic Research, http://www.nber.org/ papers/w17897 [23 October 2014].

BANISTER D., BereChMAN Y., 2001. Transport investment and the promotion of economic growth. Journal of Transport Geography, vol. 9, no. 3, pp. 209-218.

Banister D., Thurstain-Goodwin M., 2011. Quantification of the non-transport benefits resulting from rail investment. Journal of Transport Geography, vol. 19, no. 2, pp. 212-223.

CP, 2014. Cestovné poriadky. http://www.cp.sk/ [7 January 2014].

Crescenzi R., Rodríguez-Pose A., 2012. Infrastructure and regional growth in the European Union. Papers in Regional Science, vol. 91, no. 3, pp. 487-513.

ČSD, 1974. Cestovné poriadky - ukážka z roku 1974. http://cestovny.szm.com/cp 1974.htm [7 January 2014].

Gibbons S., LyytikÄInen T., Overman H., Sanchis-Guarner R., 2012. New road infrastructure: to increased regional output, increased per capita incomes, and hence increased welfare (Vickerman et al. 1999).

\section{Acknowledgements}

This contribution has been prepared under project no. 2/0086/12 Endogenous potential and exogenous factors of local and regional development in Slovakia, financed by the VEGA Grant Agency.

Editors' note:

Unless otherwise stated, the sources of tables and figures are the author's, on the basis of their own research.

The effects on firms. SERC Discussion Paper 117, London: Spatial Economics Research Centre.

Google Maps, 2014. Google Maps. http://www. google.sk/maps/ [7 January 2014].

Halás M., 2005. Dopravný potenciál regiónov Slovenska. Geografie - Sborník ČGS, vol. 110, no. 4, pp. 257-270.

HaLL D.R., 1999. Conceptualising tourism transport: Inequality and externality issues. Journal of Transport Geography, vol. 7, no. 3, pp. 181-188.

Hensher D.A., Truong T.P., Mulley C., 2012. Assessing the wider economy impacts of transport infrastructure investment with an illustrative application to the North-West Rail Link project in Sydney, Australia. Journal of Transport Geography, vol. 24, no. 9, pp. 292-305.

Holl A., 2004. Manufacturing location and impacts of road transport infrastructure: empirical evidence from Spain. Regional Science and Urban Economics, vol. 34, no. 3, pp. 341-363.

Horñák M., 2006. Dopravná infraštruktúra analýza kontextu regionálneho rozvoja $v$ predtransformačnom období [in:] k'. Faltáan (ed.), Regionálna diferenciácia Slovenska v podkladových štúdiách, Bratislava: Sociologický ústav SAV, pp. 392-406.

JaKUbiak M., Kolesar P., IzVORSKI I., KuREKOVA L., 2008. The automotive industry in the Slovak Republic: Recent developments and impact on growth. Commission on Growth and 
Development Working Paper, no. 29. Washington: The World Bank.

Knowles R., Fererache F., 2014. An investigation into the economic impacts on cities of investment in light rail systems. Birmingham: UK Tram Ltd.

KOREC P., 1984. Geografické aspekty rozvoja cestnej dopravy na Slovensku. Acta Facultatis Rerum Naturalium Universitatis Comenianae. Geographica, no. 23, pp. 183-196.

KoreC P., Ondoš S., 2009. Regional structure of the Slovak Republic in the works of Slovak geographers [in:] V. Ira (ed.), Slovak geography at the beginning of the 21st century, Geographia Slovaca, 26, Bratislava: Geografický ústav SAV, pp. 101-119.

Krajanová D., 2014. Strihanie pásky na D1 sa odkladá, tento rok pribudne len obchvat. SME, pp. 20-21, http://ekonomika.sme.sk/c/7387538/ strihanie-pasky-na-d1-sa-odklada-tento-rokpribudne-len-obchvat.html [7 December 2014].

KubASÁKOVÁ I., 2011. Rozmiestnenie logistických centier a parkov na Slovensku. Autobusy: Technika, Eksploatacja, Systemy Transportowe, no. 12, pp. 215-222.

KUBÁČEK J. (ed.), 1999. Dejiny železníc na území Slovenska. Bratislava: Železnice Slovenskej Republiky.

Kulla M., 2013. Súčasný stav a vývojové trendy $\checkmark$ elektrotechnickom priemysle Slovenska. Acta Geographica Universitatis Comenianae, vol. 57, no. 1, pp. 31-49.

LAKSHMANAN T.R., 2011. The broader economic consequences of transport infrastructure investments. Journal of Transport Geography, vol. 19, no. 1, pp. 1-12.

LALL S.V., 2007. Infrastructure and regional growth, growth dynamics and policy relevance for India. The Annals of Regional Science, vol. 41, no. 3, pp. 581-599.

LUKNIŠ M., 1985. Regionálne členenie Slovenskej socialistickej republiky z hladiska jej racionálneho rozvoja. Geografický časopis, vol. 37, no. 2-3, pp. 137-163.

Marada M., Květoñ V., VondráČKová P., 2006. Železniční doprava jako faktor regionálního rozvoje. Národohospodářský obzor, vol. 4, no. 4, pp. 51-59.

Martin P., Rogers C.A., 1995. Industrial location and public infrastructure. Journal of International Economics, vol. 39, no. 3, pp. 335-351.
MDVRR SR, 2014. Súhrnné ekonomické ukazovatele $v$ odvetví dopravy. Bratislava: Ministerstvo dopravy, výstavby a regionálneho rozvoja SR, http://www.telecom.gov.sk/ [7 January 2014].

MiCHÁLEK A., 2004. Meranie chudoby v regiónoch (okresoch Slovenska). Sociológia - Slovak Sociological Review, vol. 36, no. 1, pp. 7-30.

Michálek A., Madauová M., Podolák P., (in press). Multi-dimensional analysis of regional disparities in Slovakia. Moravian Geographical Reports.

MiChálek A., Veselovská Z., 2014. Poverty risk in districts of the Slovak Republic. Social Indicators Research, DOI 10.1007/s11205-014-0785-5.

MiCHNIAK D., 2006. Accessibility of the railway network in Slovakia. Europa XXI, 15, pp. 51-61.

MINV SR, 2014. Dopravná nehodovost'v Slovenskej republike. Bratislava: Ministerstvo vnútra SR, http://www.minv.sk/ [9 June 2014].

NDS, 2014. Národná dial'ničná spoločnost'. http:// www.ndsas.sk [26 May 2014].

NiJkAmP P., 1986. Infrastructure and regional development: A multidimensional policy analysis. Empirical Economics, vol. 11, no. 1, pp. 1-21.

Oosterhaven J., KnaAp T., 2003. Spatial economic impacts of transport infrastructure investments [in:] A. Pearman, P. Mackie, J. Nellthorp (eds.), Transport projects, programmes and policies: Evaluation, needs and capabilities. Aldershot: Ashgate, pp. 87-105.

OP Transport, 2007. Operational Programme Transport 2007-2013. Bratislava: Ministry of Transport, Posts and Telecommunications of the Slovak Republic.

Podhorský F., 1974. Doprava [in:] P. Plesník, M. Lukniš, J. Princ (eds.), Slovensko. L'ud - 1 čast', Bratislava: Obzor, pp. 183-210.

PR1BINA, 2013. PPP - R1 PR1BINA. http://www. pr1bina.sk [25 February 2014].

Redding S.J., Turner M.A., 2014. Transportation costs and the spatial organization of economic activity. NBER Working Paper Series, 20235, Cambridge: National Bureau of Economic Research, http://www.nber.org/papers/w20235 [23 October 2014].

Rietveld P., Nijkamp P., 1992. Transport and Regional Development. Research-Memorandum 1992-50, Amsterdam: Vrije Universiteit.

Rodrigue J.P., Comtols C., Slack B., 2013. The geography of transport systems. New York: Routledge. 
SACTRA, 1999. Transport and the economy: Full report. London: The Stationery Office.

SARIO, 2012. Automotive industry. Bratislava: Slovak Investment and Trade Development Agency.

VICKERMAN R., 1996. Location, accessibility and regional development: The appraisal of Trans-European networks. Transport Policy, vol. 2, no. 4, pp. 225-234.

Vickerman R., Spiekermann K., Wegener M., 1999. Accessibility and economic development in Europe. Regional Studies, vol. 33, no. 1, pp. 1-15.
WięcKowski M., Michniak D., Bednarek-SzczepańsKa M., Chrenka B., Ira V., Komornicki T., Rosik P., Stępniak M., Székely V., Śleszyński P., ŚWIĄTEK D., WIŚnIEWSKI R., 2012. Polish-Slovak borderland: Transport accessibility and tourism. Prace Geograficzne, 234, Warszawa: Instytut Geografii i Przestrzennego Zagospodarowania PAN.

ZÁvodskÝ T., 2008. Porovnanie priemernej rýchlosti dosiahnutia v železničnej doprave na jestvujúcich a modernizovaných tratiach. Železničná doprava a logistika, vol. 4, no. 1, pp. 68-74. 
http://rcin.org.pl 